\title{
CIF/IFC Gold Medal Winners Gagnants de la médaille d'or de l'institut
}

Bradley McKinnon

Sault College of Applied Arts and Technology

Bradley McKinnon of Sault Ste. Marie received the prestigious CIF/IFC Gold Medal for his overall standing and outstanding contributions to the forestry technician program at Sault College of Applied Arts and Technology. He will be attending Lakehead University in September 2001 to pursue a science degree in biology. He hopes to follow that with an education degree, so that he can become a secondary school science teacher in Ontario.

\section{Dany Prebinsky \\ Cégep de Chicoutimi}

Monsieur Prebinsky est un étudiant exemplaire tant pour la qualité de son travail que pour sa personnalité. Il est toujours ponctuel, attentif et sérieux, tout en démontrant un grand intérêt pour les différents aspects de la foresterie.

Faisant preuve d'une curiosité constante pour parfaire ses connaissances, il ne ménage pas les efforts pour trouver réponse à ses interro-

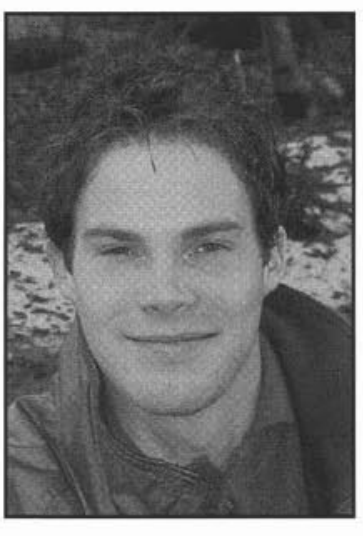
gations. Efficace, autonome et consciencieux, il exécute les tâches pratiques lors des ateliers-terrain avec précision et efficience.

En plus de présenter un dossier académique remarquable, Monsieur Prebinsky s'est impliqué tout au long de sa formation dans les diverses activités étudiantes.

Ces qualités en font un étudiant exceptionnel qui saura très certainement faire honneur à la profession de technologue forestier.

\section{Patrick Bazinet Collège Boréal}

Notre récipiendaire pour la médaille d'or de l'IFC se nomme Patrick Bazinet. Originaire de Verner, en Ontario, Patrick a su se démarquer de la moyenne académique du groupe tout au long des ses études en Technologie forestière au Collège Boréal et ceci en maintenant une moyenne pondérée parfaite de $4 / 4$. De plus, en tant que tuteur il n'hésite pas à appuyer ses collègues de classe dans leurs projets et études. Patrick est un

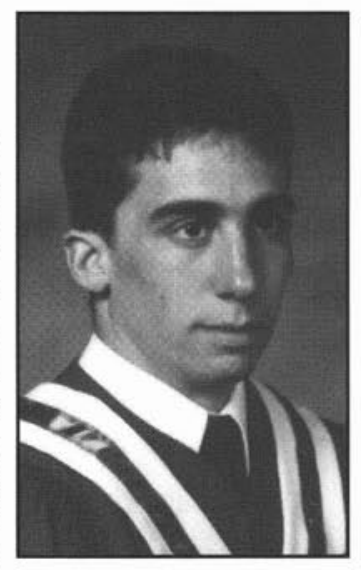
passionné des activités de plein-air comme la chasse au chevreuil, à l'orignal, la pêche et le camping.
Au cours de dernier semestre, il a effectué un stage de deux mois au sein de la compagnie Vermillion Forest Resources Management Company Inc. de Sudbury. Les contacts qu'il a su établir et son excellent travail durant son stage lui permettront sûrement de se décrocher un emploi à temps plein dans un avenir rapproché. Nous lui souhaitons donc une carrière remplie de défis.

Marc Nellis, R.P.F.

\section{David Lévesque \\ Finissant en Technologie forestière Cégep de Rimouski}

Depuis mon jeune âge, la nature et le plein air sont tout ce qu'il y a de plus précieux pour moi et c'est pour cette raison que j'ai décidé de faire un travail qui se rapproche énormément de cette passion. Cet amour pour la nature est tellement fort, qu'à chaque fin de semaine pendant mes

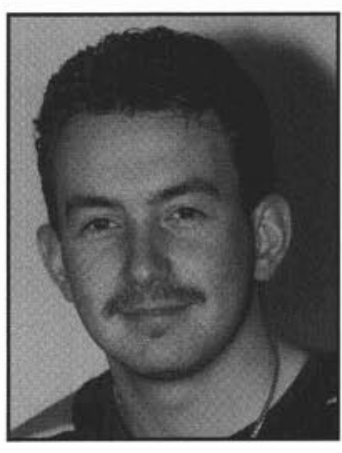
emplois d'été et même pendant l'hiver, je me suis retrouvé sur la terre de mes parents pour y effectuer différents travaux ainsi que pour m'y reposer. Pendant mes trois années au Cégep de Rimouski, cette terre a été pour moi l'endroit rêvé pour mettre en application toutes les différentes notions apprises dans nos cours.

Mes projets pour le futur sont très variés, ils s'étendent des voyages de chasse et de tourisme, d'achat de lots boisés, d'exploitation d'érablière, en passant par un projet de ferme forestière et même par un éventuel retour aux études pour entreprendre un baccalauréat en sciences forestières ou en géomatique.

\section{Daniel Gagné \\ Cégep de Baie-Comeau}

Monsieur Gagné est le récipiendaire de la médaille de l'Institut forestier du Canada. C'est un élève appliqué et respecté par son entourage. Monsieur Daniel Gagné a fait preuve de leadership et d'esprit de décision tout au long de son programme en technologie forestière au cégep de Baie-Comeau. Monsieur Gagné cumule déjà 6 mois d'expérience ayant réalisé deux stages rémunérés pendant sa formation. Monsieur

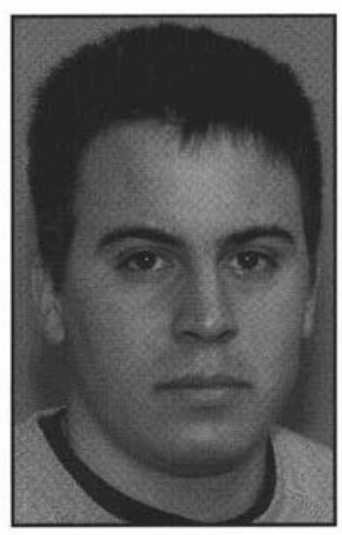
Gagné a su s'impliquer dans la promotion de la foresterie. Il a toujours été disponible pour aider à l'organisation d'activités spécifiques et a su démontrer un sens de l'organisation et d'esprit d'initiative. Apprécié de ses employeurs et persévérants dans ses entreprises, Monsieur Gagné peut maintenant compter sur une formation de haut niveau pour entamer une carrière dans le domaine forestier. 
Nicholas Duval Cégep de Sainte-Foy

Natif de Saint-Pascalde-Kamouraska, Nicholas obtient son diplôme d'études secondaires à la polyvalente ChanoineBaudet. Nicholas est un étudiant intéressé, curieux, qui fait preuve d'assiduité

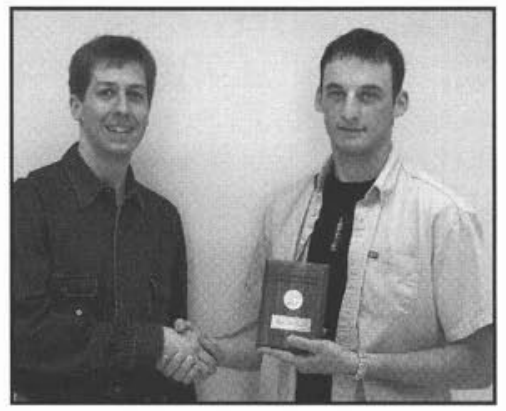
et de maturité. Au Cégep, il participe activement au Salon de la forêt présenté par la Faculté de foresterie de l'Université Laval.

L'été, il travaille pour le Groupement forestier Saint-Alexandre, tout près de chez lui, où il effectue des tâches comme du débroussaillage et du reboisement en forêt privée. Nicholas commencera d'ailleurs à travailler pour le Groupement à la fin de son DEC en mai puisque ce dernier lui a offert un emploi comme technologue forestier.

Sportif, Nicholas pratique régulièrement le hockey et le baseball. De plus, il travaille avec son père sur le lot forestier familial où ils aménagent la forêt à l'aide de deux chevaux.

Cette année, en plus de la médaille d'or de l'Institut forestier, Nicholas s'est mérité la bourse Méritas de 500 offerte par l'Ordre des technologues professionnels du Québec et un certificat cadeau de $100 \$$, gracieuseté de Dendrotik.

\section{Mélanie Beaulieu \\ Cégep Abitibi-Tmiscamingue}

Le 8 mai dernier, l'étudiante finissante en Technologie forestière, Mélanie Beaulieu, recevait la Médaille d'or du mérite forestier. Cette distinction honorifique est attribuée chaque année par l'Institut forestier du Canada, à une ou un étudiant qui se démarque par ses résultats académiques et par son engagement dans le milieu collégial

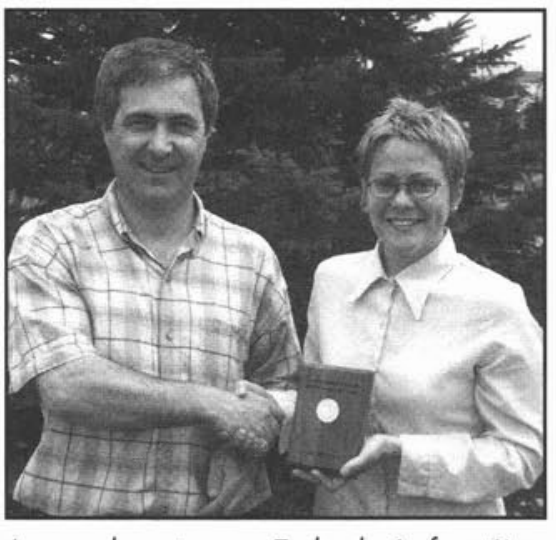
Le coordonnateur en Technologie forestière, Richard Lefebvre, remet la médaille à Mélanie Nadeau.

de l'établissement participant.

Les étudiants des programmes de formation des niveaux secondaire, collégial et universitaire, reliés à la foresterie, sont également éligibles à cette marque de reconnaissance.

Mélanie a également retenu l'attention au cours de la finale régionale 2000 de Chapeau, les filles! dont elle a été l'une des récipiendaires. Cette année, les enseignants du département de Technologie forestière ont retenu d'elle son enthousiasme et sa passion à l'égard du domaine forestier. Mélanie, qui abordera sous peu le monde du travail, a d'ailleurs à son actif plusieurs expériences pratiques et variées. Elle demeure consciente qu'une pratique forestière intelligente est liée au respect de l'environnement.
Kyle Runzer

Selkirk College

Kyle is the winner of the CIF Gold Medal for 2001. Kyle maintained the highest GPA in the two-year Forestry Program at Selkirk College and participated fully in school activities. The Department is proud of his accomplishments.

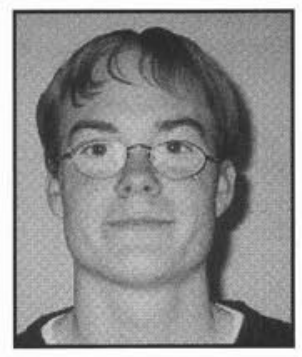

\section{Kara Ashton \\ Sir Sandford Fleming College}

Kara Ashton is this year's recipient of the CIF Gold Medal award in the Forest Technician program. She was able to maintain a high academic standing throughout her two years at the college. During her second year, Kara was recognized as the individual to initiate a low-cost "in-house"

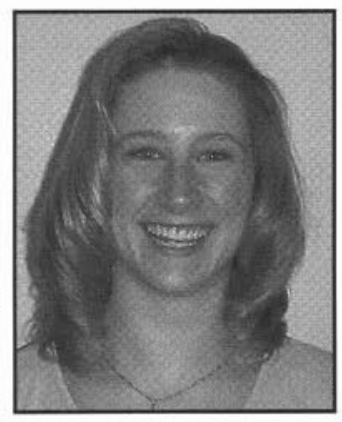
yearbook for the forestry students. Her incredible effort was much appreciated by the forestry students. Kara's hometown is Upper Rawdon, N.S. and this is why she plans to continue her education next year by attending Holland College, P.E.I. for law enforcement. This summer she is working in the forest of Nova Scotia as a veteran fire fighter and as a cruiser collecting old-growth data. We, the faculty, know that Kara's strong desire to succeed and her leadership qualities will take her far.

\section{Jennifer Chikoski \\ Lakehead University}

Jennifer Chikoski was born and raised in Thunder Bay, Ontario and recently graduated from the Honours Bachelor Environmental Studies (Forest Conservation) program at Lakehead University. Jennifer is interested in studying the impacts of human activity including both infrastructure and leisure activities on wildlife habitat. She has spent many summers studying

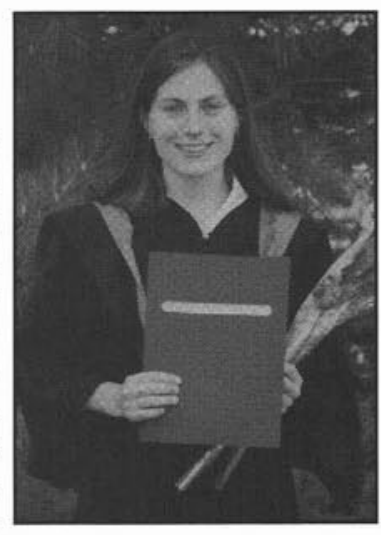
various animals and their habitat such as grizzly bears, salamanders and birds. Her favourite classes at Lakehead University were those that involved forest wildlife and soil/animal interactions. Her honour's thesis studied the effects of water addition on soil arthropods in prairie soils. Jennifer has received an NSERC scholarship to start a Masters of Science degree in wildlife biology at Lakehead University.

\section{Herman Stegehuis \\ University of Alberta}

Herman entered the University of Alberta Forest Management Program in the fall of 1997 with the support of his employer, Alberta Land and Forest Service. While continuing his employment as a Forest Protection Technician, he completed 
three courses per semester finishing his degree requirements in December 2000. Herman has been a Forest Officer for the past 20 years and in recent years has specialized in the integration of Forest Management and Forest Protection at the landscape level. Herman credits his successful educational experience to support he received from his wife Annette, and children Elice, Emily, and Jeremy. Herman continues to live in Whitecourt and has recently achieved a promotion to a Wildland Fire Prevention Officer position.

\section{Ryan Spooner}

\section{College of New Caledonia}

Ryan Spooner is the 2001 recipient of the CIF Gold Medal Award. The presentation was made by Keith McClain, Past Chair, Cariboo Section. Ryan was a student at the College of New Caledonia and while in attendance, he demonstrated academic excellence and contributed much to the

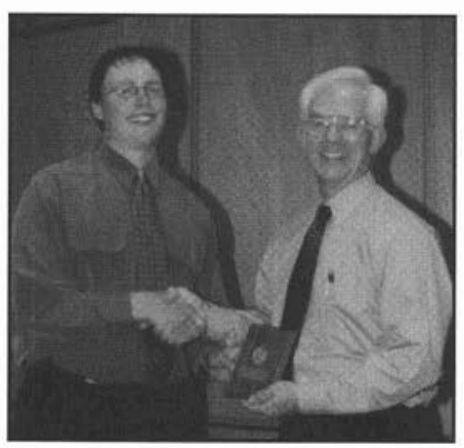

Ryan Spooner receiving the CIF Gold Medal form Keith Mclain. success of the college's forestry program. Ryan is now an employee of Integrated Silviculture Services, a Prince George forestry consulting firm. Members of the Cariboo Section wish Ryan all the best in his future work in forestry.

\section{Evelyne Thiffault \\ Université Laval}

La médaille d'or de l'Institut a été remise à madame Evelyne Thiffault, finissante du programme en aménagement et environnement forestiers. Madame Thiffault s'est illustrée tout au long de son baccalauréat par son implication dans le mouvement étudiant, jouant tour à tour les rôles de présidente de la Semaine des sciences forestières

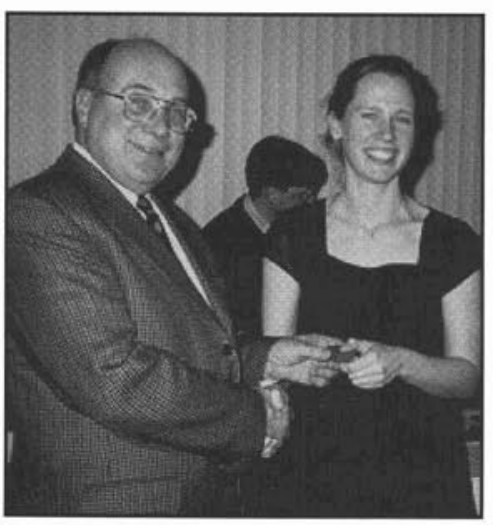
et de présidente de l'association étudiante de sa faculté, tout en présentant un dossier académique remarquable. Notons que madame Julie Dubois, également finissante du programme d'aménagement et environnement forestiers, s'est vue décerner le prix de l'Ordre des ingénieurs forestiers du Québec. Ce prix est remis lui aussi à un(e) finissant(e) s'étant particulièrement illustré(e) par la qualité de son dossier académique et par son implication dans la vie étudiante. Dès la session d'été 2001, mesdames Thiffault et Dubois entreprendront toutes deux des études de maîtrise en sciences forestières à l'Université Laval. La qualité de leur dossier respectif leur a valu l'obtention de bourses d'études du Conseil de recherche en sciences naturelles et en génie (CRSNG). Pour la qualité de son dossier, madame Thiffault s'est également vue attribuer, d'une part, la bourse
Julie Payette, dont la valeur annuelle s'élève à 25000 \$, remise à 24 personnes à travers le Canada et choisies parmi tous les récipiendaires d'une bourse CRSNG, et d'autre part, la médaille d'argent du Gouverneur général du Canada, remise à deux exemplaires dans chaque université aux meilleurs étudiants de baccalauréat en sciences humaines et en sciences naturelles et de la santé.

\section{Jennifer George NAIT}

The winner of the Gold Medal in NAIT Forest Technology for 2001 is Jennifer George. In addition to this award Jenn was a recipient of five other awards/ scholarships in the two years of the program. During the past year Jenn served as a sports representative on student council. She has acted as a counsellor for mentally and physically challenged adolescents. She spent one summer as a herbicide

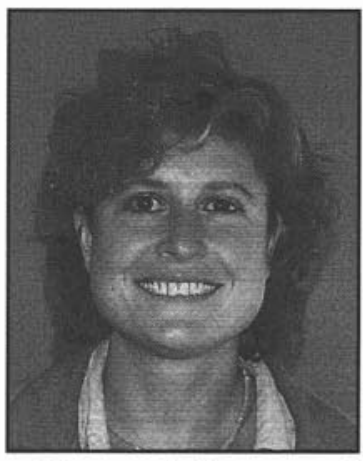
applicator for Excel Vegetation and is now in her second year with Alberta Newsprint Company as a silviculture assistant. She has an interest in forest genetics and eventually hopes to form her own consulting company.

\section{Dan Brown UNBC}

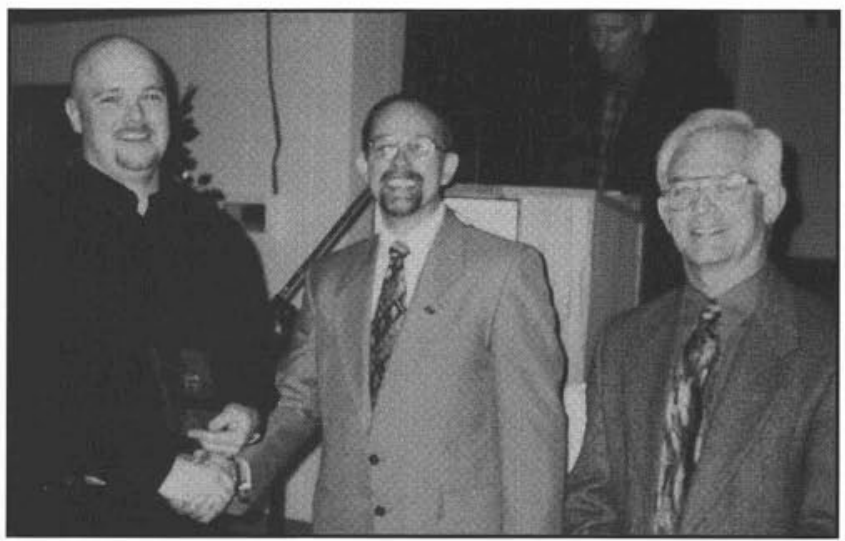

Presentation of the Gold Medal to lan Brown (left) by Don Gelinas (centre) and Keith McClain (right).

Following the presentation of the Silver Rings, Art Fredeen announced the recipient of 2001 CIF/IFC Gold Medal, which was presented to Ian Brown by Don Gelinas and Keith McClain. Ian has had a very successful academic career. Ian completed his Forest Resource Technical Diploma at the College of New Caledonia, receiving the Governor General's Gold Medal Award and later enrolled in the forestry program at UNBC. Throughout university, Ian maintained distinguished academic standing, which, in addition, was recognized by him receiving the UNBC - NRES Student Achievement Award. Congratulations Ian. 
Aaron Racher

Malaspina University-College

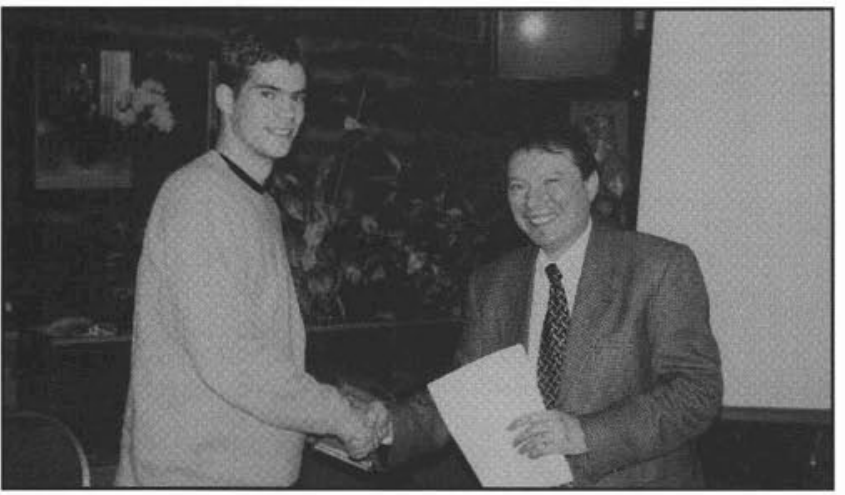

Aaron Racher was born in Alberta but migrated west to the Courtenay area of Vancouver Island at a young age. His stepfather, Harold Macy, operates a woodlot licence and manages the forestry operations of the UBC research facility in the area. Aaron started his career in the forest industry as a member of the Junior Forest Warden and plans to carry on by moving on to UBC in the fall of 2001 to complete an undergraduate degree in forest resources administration and engineering. With his high scholastic achievements from the Malaspina University-College Forest Resources Technology program and his dedication, Aaron will, no doubt, be very successful in the UBC program.

\section{Paul Filippelli BCIT}

Paul Filippelli is the recipient of the 2001 CIF Gold Medal in the Forest Technology diploma program. Paul is graduating this spring, after completing the second year of his studies at BCIT. While there, he has achieved top academic standing and played an active role in the student community. He was involved in the BCIT Open House exhibits and was active-

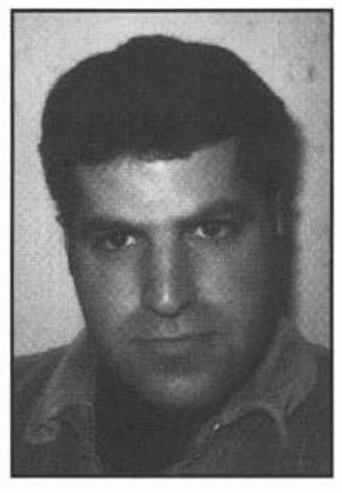
ly promoting sustainable forestry in the community based EcoFair.

Paul is a member of the intramural floor hockey and baseball teams at BCIT and enjoys mountain biking on his time off. Born and raised in Vancouver, B.C., he developed a love for the outdoors at an early age. He began his forestry pursuit in 1995 working for FTCL Forestactics, a firm of consulting foresters based in Burnaby, B.C., and looks forward to a career in forest management after graduation.

\section{Anthony Boyd \\ University of British Columbia}

Anthony Boyd had his first exposure to the forest industry in 1997 when working Fire Suppression for the B.C. Ministry of Forests. This experience solidified his goal of becoming a forest engineer, which led him to UBC. The Faculty of Forestry motivated him to graduate with a Bachelor of Science in Forestry, majoring in Forest Operations, which will be followed by a year to fulfil the professional engineering requirements. His future plans involve working towards joint professionalism, seek-

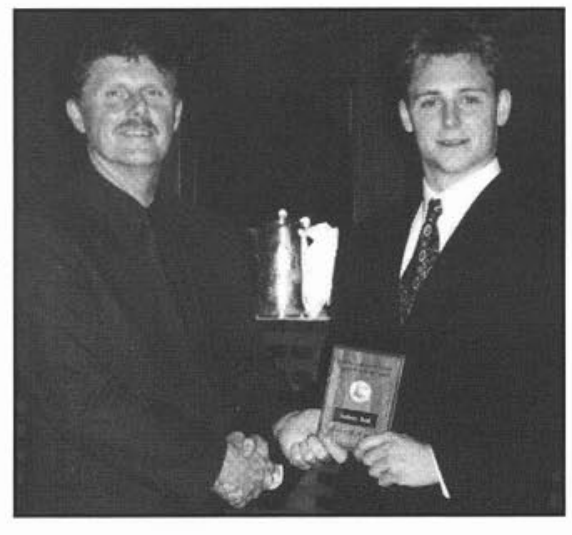
ing accreditation from both $\mathrm{ABCPF}$ and $\mathrm{APEG}$.

While at UBC, Anthony held several positions with the Forestry Undergraduate Society (Social Co-ordinator, Special Events Co-ordinator). This volunteer work was very rewarding, enabling him to interact with students and faculty which has forged friendships that will last a lifetime. In his final year, Anthony received both the Malcolm Knapp Spring Camp Prize and the Weyerhaeuser Fellowship in Forestry Award. Anthony is currently on the graduation committee to help organise and fundraise for this year's graduation banquet.

In his spare time, Anthony plays intramural hockey, basketball, soccer, co-ed futsal, and enjoys attending the annual forestry ski trip. In May, he will be working with Weyerhaeuser-Port McNeill Timberlands as an assistant Field Planner.

\section{Daniel Caissie}

Bathurst Campus of the Maritime Forest Ranger School

Daniel Caissie of Rogersville N.B. is this year's (2000) recipient of the Canadian Institute of Forestry Gold Medal Award, at the Bathurst Campus of the Maritime Forest Ranger School. Daniel came to the school after graduating from the Vocational Forest Worker Course at NBCC

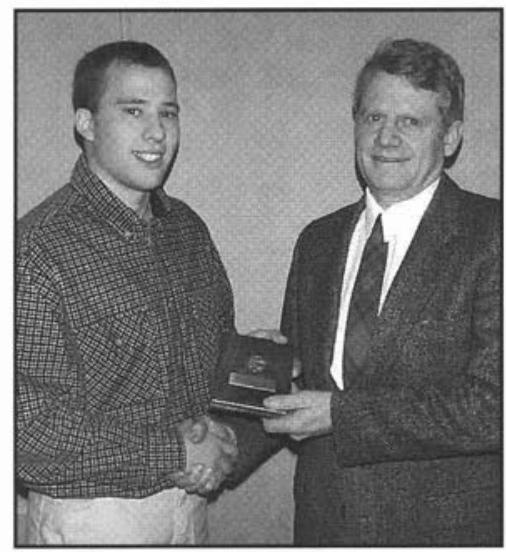

Blaire Vessie presents Daniel Caissie with the Gold Medal.
Miramichi N.B. and working two years in Silviculture. The knowledge he gained from his previous course and forestry experience made him an exceptional individual in practical forestry and was looked upon by his fellow students as the class leader always willing to help individuals as well as a great project organiser. He not only excelled in practical work but also had the highest-class average for the year. He was also the winner of the Silviculture prize for having the highest average in Silviculture. After an interview with a major Forestry Company, the signing of the documents was all that was left to securing a job.

It is our pleasure to introduce Daniel to you and to have presented the prestigious CIF Gold Medal to such a deserving individual. 


\section{Brendan Hemens}

University of New Brunswick

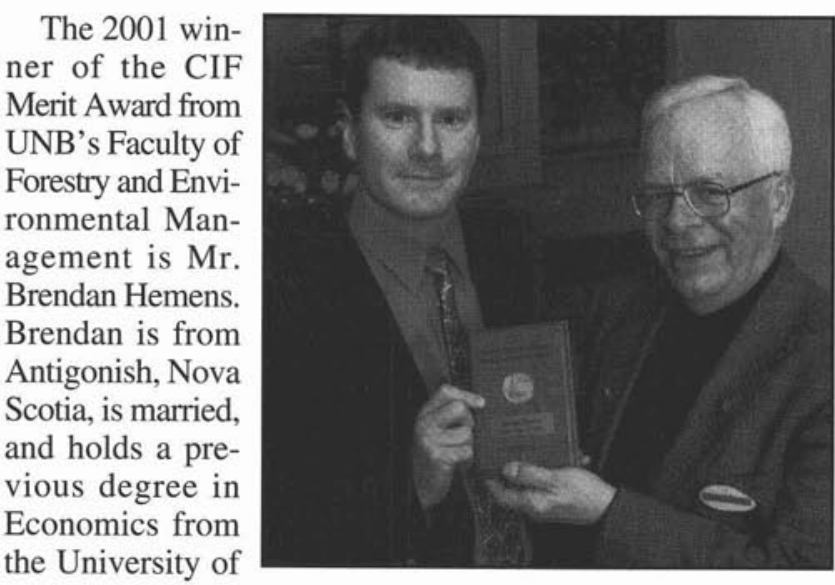

Toronto. Brendan is an exceptional scholar. He has also helped the Faculty and his peers in many ways, notable among them as a Teaching Assistant in many courses and as a student spokesman for the Faculty's Advisory Board. Brendan's honors thesis is titled "An Examination of Partial Harvesting in Spruce/Fir Stands" and he has been awarded an NSERC scholarship to pursue graduate studies at UNB in the field of natural disturbance regimes in association with Bioforest Technologies of Sault Ste. Marie, ON.

\section{Maryse Gagnon}

Université de Moncton

Madame Maryse Gagnon, originaire de StJoseph-de-Madawaska au Nouveau-Brunswick, s'est vue accordée la médaille d'or de l'Institut forestier du Canada pour l'École de sciences forestières de l'Université de Moncton. Cette distinction est attribuée annuellement à un étudiant ou une étudiante qui s'est illustré durant ses études de baccalauréat

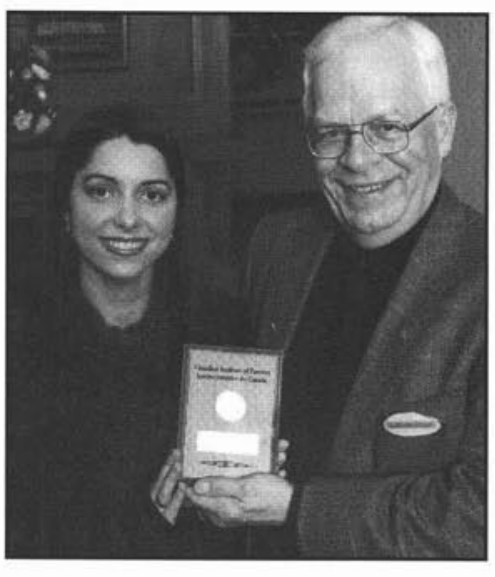
en sciences forestières par l'excellence de son dossier académique, ainsi que par ses qualités personnelles. Madame Gagnon a maintenu un rendement académique élevé tout a long de sa formation, tout en étant impliquée dans la vie étudiante et dans les activités de la communauté universitaire. Elle fait partie du premier groupe de finissants du régime coopératif mis en place à l'ÉSF en 1997. Tout au long de son cheminement, dans ses cours comme lors des stages en milieu de travail, madame Gagnon a démontré un sens aigu de la rigueur et de la discipline, un sens des responsabilités développé, et un esprit de camaraderie qui en font une personne dont les conseils sont sollicités par ses collègues. Toutes ses qualités en font une étudiante remarquable. Toutes nos félicitations à Maryse Gagnon et tous nos souhaits de succès dans ta carrière.

\section{Richard Kosan}

Algonquin College

Richard Kosan was chosen from among a very worthy class to be the recipient of the 2000 CIF Gold Medal for outstanding scholarship, sports and citizenship. Richard hails from Windsor, Ontario, where he worked in the high-energy emergency field as a paramedic. While in the Forestry Technician Program, at Algonquin College, Richard made the Dean's Honour Roll in each semester and graduated with a cumulative GPA of "A." He was a faithful participant at the gym which put him in very good condition for his various outdoor pursuits, like Ultimate Frisbee.

Richard volunteered his services to a number of activities such as the Eastern Ontario Renfrew County Woodlot Conference, the Arnprior Deer Check Station, the Pembroke Waterfront Improvement Project and the Prairie Ecosystem Restoration Project in Windsor. However, his fellow classmates will remember him best for being a patient tutor especially during their time of need before a major exam. Even with this pace, Richard was able to obtain a number of industry certificates, which bodes well for his present supervisory position with a forestry firm in Calgary.

Richard has this to say about receiving the award. "I would like to share this award with my fellow classmates who worked just as hard as me and I would like to thank the Forestry staff who were very instrumental in my success." The Faculty wish Richard all the best.

\section{Kerri McMillan \\ Lakehead University}

Originally from Red Rock Ontario, Kerri McMillan is the recipient of the CIF gold medal award for the 2001 Honors Bachelor of Science in Forestry graduating class at Lakehead University in Thunder Bay. Kerri's education began in the health sciences industry as she completed a diploma in Medical Radiation Technology. While completing this diploma

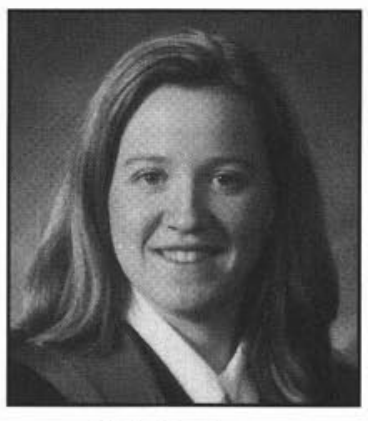
Kerri was employed in a pulp and paper mill in her hometown where her curiosity about the forest industry began. Upon completion of her diploma, Kerri immediately began studying forestry at Lakehead University. Kerri approached her studies keeping in mind that being part of the forest industry also means supporting the community, in this case the university community. While at Lakehead Kerri was a member of a faculty review committee and task force; she was the public relations representative for the Lakehead University Forestry Association, and the cochairperson for the CIF Silver Ring Ceremony. Outside of the university, Kerri competed competitively in curling and enjoyed volunteering for various committees. As well as being the recipient of the CIF gold medal, Kerri was chosen for a President's award. Currently Kerri is employed by Blue Ridge Lumber (1981) Ltd. in Whitecourt, Alberta, as a silviculture assistant for the herbicide program. She plans to continue career development through work experience. 


\section{Dan Sherling}

Saskatchewan Institute of Applied Science and Technology, Woodland Campus

Dan Sherling was the recipient of the 2001 CIF Gold Medal award at the Saskatchewan Institute of Applied Science and Technology (SIAST), Woodland Campus. He was born and raised in Saskatoon, Saskatchewan. He has also lived in Queen Charlotte City for five consecutive years, where he developed a great interest in forestry. Forestry became important to Dan through his belief that the forest, and its ecological diversity, is a critical environmental component contributing to the overall health of our environment, and, therefore, it has to be sustainably and responsibly managed. Since his interest in the forest was growing, he decided to increase his knowledge in that discipline. His strong academic skills, excellent communication and interpersonal skills and great sense of humor achieved his graduation from the Integrated Resource Management (IRM) Program at SIAST, Woodland Campus. He gained knowledge in the fields of forestry, wildlife, fisheries, and park management through the IRM program. He has also taken a professional computer operator course.

Dan has experience in scaling, forest health assessments, timber cruising, regeneration surveys, forest inventory, permanent sample plots and tree growth analysis. He is now working at Golder Associates Ltd. as a biological technician for the aquatics team. He is currently conducting fish habitat assessments.

Dan's professional interests are to participate with the Golder Associates team and continue in the field of aquatic engineering. His personal interests are to further his education in forestry, landuse planning or biology. His major goal is to get a degree in one of the aforementioned fields.

Golder Associates is proud to have Dan as a part of our active project teams where he brings insight and excellence to all of his duties. Congratulations to Dan for successfully achieving the CIF/IFC Gold Medal for 2001. A testament to his ability and dedication.

\section{Chris Ward \\ Maritime Forest Ranger School}

Chris came to the Maritime Forest Ranger School as a single student (20 years of age) with a background of employment at Scott's Nursery, a full service horiticultural facility in Lincoln. Chris was a very strong student with superior communications and interpersonal

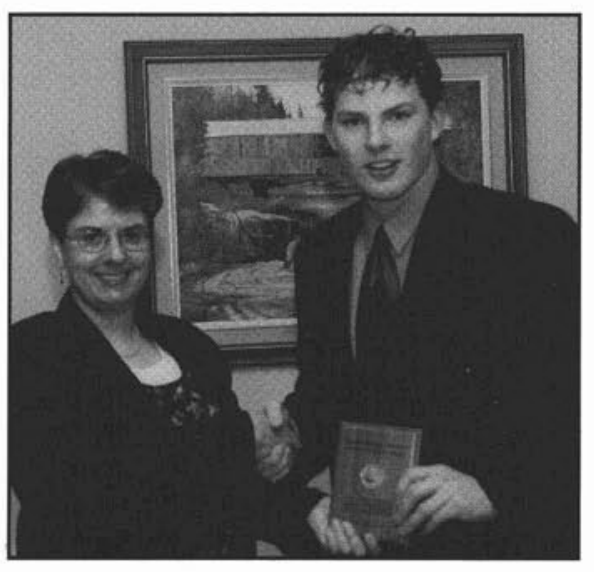
skills. He distinguished himself early on as a very capable and ever willing helper to his classmates. Upon graduation, Chris was also a recipient of the Proctors Award. This Award is sponsored by the Ranger School proctors and is presented to the two students voted by their class, who have demonstrated the best cooperative spirit in helping other students. Chris had very high standards in both field and academic aspects of his studies and was a very hard working, dedicated and determined student. We are very proud to present him to you. 